\title{
Psychological well-being is associated with better nutrient intakes in heterogeneous older populations
}

\author{
Jyväkorpi, S. K.
}

2017-02

Jyväkorpi , S K, Pitkala , K H , Björkman , M P , Strandberg , T E , Soini , H \& Suominen , M H 2017 , ' Psychological well-being is associated with better nutrient intakes in heterogeneous older populations ' , European Geriatric Medicine , vol. 8 , no. 1 , pp. 6-7 . https://doi.org/10.1016/j.eu

http://hdl.handle.net/10138/236419

https://doi.org/10.1016/j.eurger.2016.09.007

publishedVersion

Downloaded from Helda, University of Helsinki institutional repository.

This is an electronic reprint of the original article.

This reprint may differ from the original in pagination and typographic detail.

Please cite the original version. 


\section{Letter to the editor}

\section{Psychological well-being is associated with better nutrient intakes in heterogeneous older populations}

\section{Introduction}

Nutrition is essential for the overall well-being of an older individual, and psychological well-being (PWB) is an important dimension of quality of life $[1,2]$. Nutritional status is known to associate with better PWB among long-term residents with dementia, but less is known about these relationships in general older population [3]. We analyzed PWB, frailty risk, and dietary intake in various groups of older people.

\section{Methods}

Our cross-sectional study combined four datasets of nutritional studies: (1) healthy home-dwelling older people who participated in the Nutrition Education and Cooking Class (NC) follow-up study $(n=54)$ [4], (2) older men from the Helsinki Businessmen Study (HBS) ( $n=66$ ) [5], (3) home-dwelling older people with signs of frailty and screened for the Porvoo Sarcopenia and Nutrition Trial (PSNT) $(n=179)$ [6], and (4) institutionalized older residents of assisted living facilities (ALF) from the Helsinki metropolitan area
( $n=266$ ) [7]. The recruitment, eligibility and participant characteristics have been reported elsewhere [4-8].

Nutritional status was assessed using the Mini Nutritional Assessment (MNA) [9]. Energy and nutrient intakes were retrieved from 1 to 3 day food diaries. PWB questionnaire included six validated questions about (1) life satisfaction (yes/no), (2) feeling needed (yes/no), (3) having plans for the future (yes/no), (4) having zest for life (yes/no), (5) feeling depressed (seldom or never/ sometimes/often or always), and (6) suffering from loneliness (seldom or never/sometimes/often or always) [10]. In the PWB score each question represented 0 ('no' in questions $1-4$, 'often or always' in question 5 or 6 ), 0.5 ('sometimes' in question 5 or 6 ), or 1 ('yes' in questions 1-4, 'seldom or never' in question 5 or 6). The score is created by dividing the total score by the number of questions the participant had answered. Thus, a score of 1 represented the best PWB and 0 the poorest.

\section{Results}

The mean age of the participants was 82 years, and $70 \%$ ( $n=565$ ) were women. The PWB was good (score $\geq 0.80$ ) in $52 \%$ ( $n=295)$, moderate (score $=0.40-0.79)$ in $39 \%(n=219)$, and poor in $9 \%(n=51)$ of the participants. Those with lower PWB scores were older, had more risk factors of frailty, were more likely institutionalized, and had the lowest mean MNA-scores (Table 1).

Table 1

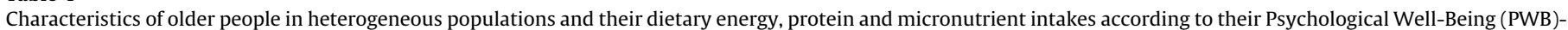
scores.

\begin{tabular}{|c|c|c|c|c|}
\hline & $\begin{array}{l}\text { PWB poor (score: } 0-0.39 \text { ) } \\
n=51\end{array}$ & $\begin{array}{l}\text { PWB moderate (score: } 0.4-0.79 \text { ) } \\
n=219\end{array}$ & $\begin{array}{l}\text { PWB good (score: } 0.8-1 \text { ) } \\
n=295\end{array}$ & $P$-value \\
\hline Age, mean (SD) & $84(7)$ & $83(7)$ & $80(8)$ & $<0.001$ \\
\hline \multicolumn{5}{|l|}{ Place of residence, \% } \\
\hline Home & 33 & 62 & 72 & $<0.001^{\mathrm{b}}$ \\
\hline Institution & 67 & 38 & 28 & \\
\hline MNA, mean (SD) & $20(4)$ & $22(4)$ & $23(3)$ & $<0.001$ \\
\hline Energy, kcal (SD) & $1606(417)$ & $1653(428)$ & $1717(461)$ & 0.04 \\
\hline Protein, g (SD) & $61(22)$ & $65(20)$ & $71(23)$ & $<0.001$ \\
\hline Total fat, g (SD) & $59(23)$ & $61(21)$ & $65(26)$ & 0.012 \\
\hline SFA & $24(11)$ & $24(9)$ & $26(10)$ & 0.116 \\
\hline MUFA & $17(8)$ & $16(8)$ & $18(12)$ & 0.130 \\
\hline PUFA & $10(7)$ & $12(9)$ & $14(9)$ & $<0.001$ \\
\hline Vitamin $A, \mu g$ (SD) & $568(371)$ & $846(1130)$ & $947(1263)$ & 0.039 \\
\hline Vitamin $\mathrm{D}, \mu \mathrm{g}(\mathrm{SD})$ & $8(7)$ & $9(7)$ & $9(7)$ & 0.093 \\
\hline Vitamin E, mg (SD) & $7(4)$ & $7(4)$ & $9(5)$ & $<0.001$ \\
\hline Thiamine, mg (SD) & $1.2(0.5)$ & $1.2(0.4)$ & $1.3(0.4)$ & 0.20 \\
\hline Vitamin C, mg (SD) & $96(55)$ & $102(62)$ & $106(65)$ & 0.25 \\
\hline Folate, $\mu g(\mathrm{SD})$ & $224(86)$ & $239(110)$ & $256(110)$ & 0.018 \\
\hline Iron, mg (SD) & $9(3)$ & $10(4)$ & $10(3)$ & 0.06 \\
\hline Zinc, mg (SD) & $9(3)$ & $10(3)$ & $11(3)$ & 0.007 \\
\hline
\end{tabular}

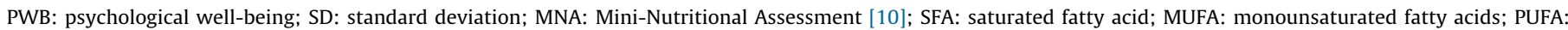
polyunsaturated fatty acids.

a Tested for linearity.

b Tested by $X^{2}$ test. 
A higher PWB score was associated with higher energy, protein total fat, polyunsaturated fatty acids, folate, vitamin A and vitamin $\mathrm{E}$, iron and zinc intakes (Table 1).

\section{Conclusion}

Higher PWB scores and lower risk of frailty were linearly associated with MNA-scores and key nutrient intakes in heterogeneous groups of older people. In earlier studies MNA-status has been associated with higher PWB scores and the present results extend PWB benefits to key nutrient intakes [3]. Consequently, nutrition interventions may have an important role to enhance the quality of life of older people.

\section{Disclosure of interest}

SKJ: reports having received lecturing fees from pharmaceutical company Actavis.

KHP: Dr Pitkälä reports having received lecturing fees from pharmaceutical companies (including Lundbeck, Orion), and having participated in clinical trials funded by pharmaceutical companies.

MPB: Dr Bjorkman has received lecture fees from Valio Ltd. and Valio Ltd. also provided the nutritional supplements used in the Porvoo sarcopenia \& nutrition trial that was started after the baseline assessments reported in this study.

TES: reports of having various educational and consultative cooperation with several companies including Nutricia, Abbott, Amgen, Merck, Pfizer, Novartis, NovoNordisk, minor amount of stock in OrionPharma, President of the European Union Geriatric Medicine Society, which has cooperation also with nutrition industry.

HS: reports no conflict of interest.

MHS: reports having received lecture fees from Nutricia and Verman Ltd.

\section{Acknowledgements}

This study was supported by The Finland's Slot Machine Association, Helsinki University Hospital EVO-funding, Oulu University Hospital EVO funding, Helsinki City, Konung Gustav V:s och Drottning Victorias Frimurarestiftelse, Yrjö Jahnsson Foundation. The sponsors did not have any role in the study design, analysis or interpretation of data, nor in writing the report or the decision to submit this article. The authors were independent researchers not associated with the funders.

\section{References}

[1] Suominen MH, Jyvakorpi SK, Pitkala KH, Finne-Soveri H, Hakala P, Mannisto S, et al. Nutritional guidelines for older people in Finland. J Nutr Health Aging 2014;18:861-7.

[2] WHO. WHOQOL-Bref. Introduction. Administration, scoring and generic version of the assessment. Field Trial Version December 1996. In: Rapley M, editor. Quality of life research. A critical introduction. London: Sage Publications; 2003.

[3] Muurinen S, Savikko N, Soini H, Suominen MM, Pitkälä K. Nutrition and psychological well-being among long-term care residents with dementia. J Nutr Health Aging 2015;19(2):178-82.

[4] Jyväkorpi SK, Pitkälä KH, Kautiainen H, Puranen TM, Laakkonen ML, Suominen $\mathrm{MH}$. Nutrition education and cooking classes improve diet quality, nutrient intake, and psychological well-being of home-dwelling older people - a pilot study. J Aging Res Clin Pract 2014;3:120-4

[5] Strandberg TE, Stenholm S, Strandberg AY, Salomaa VV, Pitkälä KH, Tilvis RS. "Obesity paradox" frailty, disability, and mortality in older men: a prospective, longitudinal cohort study. Am J Epidemiol 2013;178(9):1452-60.

[6] Bjorkman MP, Suominen MH, Pitkälä KH, Finne-Soveri HU, Tilvis RS. Porvoo sarcopenia and nutrition trial: effects of protein supplementation on functional performance in home-dwelling sarcopenic older people - study protocol for a randomized controlled trial. Trials 2013;14:387.

[7] Vikstedt T, Suominen MH, Joki A, Muurinen S, Soini H, Pitkälä KH. Nutritional status, energy, protein and micronutrient intake of older service house residents. J Am Med Dir Assoc 2011;12(4):302-7.

[8] Jyväkorpi SK, Pitkälä KH, Puranen TM, Björkman MP, Kautiainen H, Strandberg TE, et al. Low protein and micronutrient intakes in heterogeneous older population samples. Arch Gerontol Geriatr 2015;15:30022-4.

[9] Routasalo PE, Tilvis RS, Kautiainen H, Pitkala KH. Effects of psychological group rehabilitation on social functioning, loneliness and well-being of lonely, older people: randomized controlled trial. J Adv Nurs 2009;65:297-305.

[10] Vellas B, Guigoz Y, Garry PJ, Nourhashemi F, Bennahum D, Launque S, et al. The Mini Nutritional Assessment (MNA) and its use in grading the nutritional state of elderly patients. Nutrition 1999;15(2):116-22.

S.K. Jyväkorpi ${ }^{\mathrm{a}, *}$, K.H. Pitkäläa, M.P. Björkman ${ }^{\mathrm{a}}$, T.E. Strandberg ${ }^{\mathrm{b}, \mathrm{c}}$, H. Soini ${ }^{\mathrm{a}, \mathrm{d}}$, M.H. Suominen ${ }^{\mathrm{a}}$

anniversity of Helsinki, Department of General Practice and Primary Health Care, Finland

${ }^{\mathrm{b}}$ University of Helsinki, Clinicum, and Helsinki University Hospital, Helsinki, Finland

${ }^{c}$ University of Oulu, Center for Life Course Health Research, Oulu, Finland ${ }^{\mathrm{d}}$ Department of Social Services and Health Care, Developmental and Operational Support, Helsinki City, Finland

${ }^{*}$ Corresponding author at: Tukholmankatu 8 B, 00014 University of Helsinki, Finland. Tel.: +358 504920970 E-mail address: satu.jyvakorpi@gery.fi (S.K. Jyväkorpi)

Available online 27 October 2016 